\title{
Karakteristik Fisik dan Organoleptik MP-ASI Instan Diperkaya Ikan Patin dan Ikan Gabus Metode Freeze Dryer
}

\author{
Physical Characteristic Instan Baby Porridge Enhanced Catfish (Pangasius sp) and \\ Snakeheadfish (Channa Striata) with Freeze Dryer Method
}

\author{
Choiroel Anam $^{1 *}$, Kawiji ${ }^{1}$, Usada Nur Ariyoga ${ }^{1}$, Reyhan Farha ${ }^{1}$ \\ ${ }^{1}$ Program Studi Ilmu dan Teknologi Pangan - Fakultas Pertanian - Universitas Sebelas Maret Surakarta \\ Jl. Ir. Sutami 36A - Kentingan Jebres - Surakarta 57126 \\ usada.nura@gmail.com \\ choiroelanam@staff.uns.ac.id \\ kawiji14121961@gmail.com \\ reyhanf221@gmail.com
}

\begin{abstract}
ABSTRAK
Makanan Pendamping Air Susu Ibu atau selanjutnya ditulis MP-ASI merupakan produk bubur instan yang bahan penyusun bubur untuk bayi yang bersifat siap saji atau instan sehingga prinsip dalam penyajian mudah disajikan, mudah penyimpanan, dan kaya akan nutrisi. MP-ASI merupakan makanan yang berbentuk cair semi padat. Pada penelitian ini digunakan bahan pangan ikan patin dan ikan gabus sebagai bahan pembuatan bubur bayi MP-ASI instan. Penelitian dimaksudkan untuk mengetahui sifat karakteristik bubur bayi MP - ASI dari sifat fisik (kelarutan dan daya serap air) dan tingkat kesukaan dengan uji organoleptik. pada bubur bayi dengan penambahan ikan patin dan ikan gabus. Penelitian ini menggunakan rancangan acak lengkap (RAL), satu faktor yaitu konsentrasi ikan patin $(7,5 \% ; 10 \% ; 12,5 \%)$ dan ikan gabus $(7,5 \% ; 10 \% ; 12,5 \%)$. Sebagai kontrol yaitu tanpa penambahan ikan. Pengujian organoleptik, sampel bubur instan diseduh air hangat selanjutnya dilakukan pengamatan secara organoleptik dengan uji skoring dari 25 orang panelis. Pengolahan data secara statistik memakai one way anova taraf signifikansi 5\%. Pengamatan organoleptik dilakukan pada parameter tektur, rasa, warna, aroma, dan overall. Hasil penelitian karakteristik fisik untuk kelarutan memiliki rentang hasil $33-47 \%$. Untuk daya serap air memiliki rentang nilai $0,882-6,20 \mathrm{gr} / \mathrm{gr}$. Untuk hasil uji organoleptik sampel bubur bayi instan paling terbaik berdasarkan nilai skor pada sampel ikan bubur bayi instan dengan penambahan ikan gabus $12,5 \%$.
\end{abstract}

Kata kunci: Ikan Patin; Ikan Gabus; MP - ASI.

\begin{abstract}
Instant Baby Porridge is written (MP-ASI) is an instant porridge product which is a compiler component of baby porridge that is instant so that the principles in the presentation are easy to serve, easy to store, and rich in nutrients. Instant Baby Porridge (MP-ASI) is a semi-solid liquid food. In this research, catfish and snakehead fish are used as ingredients for instant baby porridge. This study aims to determine the physical characteristics of MPASI baby porridge physically (solubility and water absorption) on the addition of catfish and snakehead fish and the level of preference by organoleptic test. In this study using a completely randomized design (CRD) with one factor, namely the concentration of catfish $(7.5 \% ; 10 \% ; 12.5 \%)$ and Snakehead fish $(7.5 \% ; 10 \% ; 12.5 \%)$. As a control that is without the addition of fish. Organoleptic testing, instant porridge samples were brewed with warm water and then observed organoleptically by scoring test using 25 panelists. The data is then processed statistically using one way ANOVA with a significance level of 5\%. Organoleptic observations were made on the parameters of color, aroma, taste, texture, and overall. The results of the study of physical characteristics for solubility have a yield range of $33-47 \%$. For water absorption has a range of values of $0.882-6.20 \mathrm{gr} / \mathrm{gr}$. For the best organoleptic test results, instant baby porridge samples are based on the scores on instant baby porridge fish samples with the addition of Snakehead fish $12.5 \%$.
\end{abstract}

Keywords : Catfish; Snakehead fish; MP - ASI 


\section{Introduction}

Saat bayi menginjak usia 6 bulan, Air Susu Ibu atau ASI belum mencukupi kebutuhan gizi bayi. Maka diperlukan pendamping makanan yang bisa mencukupi kebutuhan bayi di usia sekitar 6 bulan. Makanan Pendamping Air Susu Ibu atau MP - ASI adalah makanan atau minuman untuk memenuhi kebutuhan gizi pada anak atau balita (Trahms and McKean, 2008). Pada prinsipnya MP - ASI merupakan makanan kaya nutrisi, mudah disajikan, mudah dicerna, mudah penyimpanannya dan harga yang terjangkau (Marliyati, 2007). Diperlukan perhitungan secara cermat perbandingan dan jenis bahan pada campuran beberapa komponen makanan bayi agar dihasilkan produk dengan nutrisi tinggi pada makanan bayi

MP-ASI diharapkan memiliki kandungan gizi yang dibutuhkan oleh bayi seperti protein, lemak, karbohidrat, mineral dan vitamin. Pada MP - ASI yang beredar berupa bentuk bubuk atau bubur instan, sumber karbohidrat bersumber dari serealia atau umbi - umbi dan diperkaya sumber bahan makanan protein nabati maupun hewani. Dari penelitian Elvizahro (2014) menggunakan tepung ikan patin sebagai sumber protein. Selain itu penelitian Sari (2018) menggunakan ikan gabus sebagai sumber protein untuk bubur bayi instan.

Menurut Muchtadi (1999), bahwa protein hewani memiliki protein yang lengkap serta bermutu tinggi karena memiliki kandungan asam - asam amino esensial yang lengkap dan susunannya mendekati keperuan tubuh. Protein hewani memiliki daya cerna yang tinggi sehingga jumlah yang diserap dalam tubuh juga tinggi. Kadar protein pada ikan gabus adalah 25,5\% (Nurimala et al, 2009). Pada ikan patin memiliki kadar protein sebesar 68,6\% (Elvizahro, 2014). Masyarakat di Indonesia dalam mengkonsumsi ikan sangat beragam, disebabkan rasa dan bau amis dari ikan masih menjadi masalah pada sebagian masyarakat, dan sebagian yang lain tidak dapat mengkonsumsi ikan dalam bentuk aslinya.

Cara yang bisa diusahakan antara lain dengan menyiasati ikan dijadikan bahan sebagai fortifikan protein produk pangan yang dalam aplikasinya dapat disajikan dalam berbagai bentuk antara lain bentuk ikan lumat, konsentrat protein ikan ( KPI), surimi dan hidrolisat protein ikan ( HPI) Irianto, (2020). Pada ikan lumat sebaiknya menggunakan ikan dari daging putih yang bisa didapatkan dari ikan air tawar maupun ikan laut. Caranya daging dipisahkan dalam bentuk fillet, dilanjutkan proses pelumatan menggunakan silent cutter atau penggiling daging. Metode yang lain bisa juga dipakai meat bone separator, artinya ikan yang telah di fillet atau dibelah dimasukkan pada alat tersebut sehingga akan diperoleh daging ikan lumat. Pada peneitian sebelumnya, bubur bayi sebagai MPASI yang disampaikan dengan kombinasi labu kuning sebagai potensi sumber karbohidrat, bayam, dan kacang merah diharapkan dapat untuk sumber protein. Pada penelitian ini ditambahkan ikan patin (Pangasius sp) dan ikan gabus (Channa striata) sebagai bahan untuk memperkaya dan penunjang kadar protein.

Penelitian ini perlu dilakukan untuk mengkaji pengaruh atau dampak penambahan ikan patin dan ikan gabus pada karakteristik fisik bubur instan (kelarutan dan daya serap air). Selain itu juga untuk mengetahui sifat organoleptik (Rasa, aroma, warna, tekstur, dan overall) pada bubur bayi MP - ASI instan .

\section{Method}

Bahan labu kuning yang digunakan dalam penelitian ini didapat dari petani di daerah Boyolali, kacang merah dari pasar kota Klaten, bayam hijau dari sentra pasar Tawangmangu, ikan patin dan ikan gabus dari sentra ikan segar kota Surakarta, susu formula dengan merek dagang SGM umur $0-6$ bulan, minyak nabati kedelai, dan air mineral. Alat - alat yang dipakai untuk penelitian ini pisau blender, alat pengering freeze dryer (Chris alpa), oven, desikator, tanur pengabuan, soxhlet,dan desikator,

Rancangan percobaan pada penelitian ini yakni Rancangan Acak Lengkap (RAL) dengan satu faktor yaitu variasi konsentrasi penambahan ikan menggunakan pengulangan sampel sebanyak dua kali dan pengujian analisis juga dua kali. Data yang diperoleh kemudian dianalisis secara statistik dengan metode oneway ANOVA. Kemudian data dianalisis lanjutan dengan analisis beda nyata yaitu Duncan's Multple Range Test (DMRT) memakai taraf signifikansi $\alpha=0,05$. 


\subsection{Pembuatan Puree}

Pembuatan bubur bayi instan dilakukan berdasarkan penelitian sebelumnya, Atika (2014) dan adanya modifikasi. Pembuatan puree bubur bayi dilakukan pada masing - masing bahan yaitu: buah labu kuning, kacang merah, dan bayam hijau, ikan patin, dan ikan gabus. Labu kuning dikupas kemudian cuci bersih, dilakukan pemotongan berbentuk dadu kemudian dikukus. Setelah dikukus dilakukan penghalusan dengan blender. Bahan bayam hijau dicuci dengan air mengalir lalu dipisahkan antara daun dan batang. Kemudian dilakukan pengukukusan setelah itu dihaluskan dengan mesin blender. Bahan kacang merah sebelumnya direndam selama 6 jam setelah itu dicuci dengan air mengalir. Kemudian dilakukan pengukusan. Setelah dikukus dihaluskan dengan mesin blender. Pada bahan ikan patin dan ikan gabus semua difillet daging dipisahkan kulit dan durinya yang masih menempel, kemudian dicuci dengan air mengalir dan setelahnya dilakukan pengukusan. Setelah pengukusan dilakukan penghalusan dengan mesin blender.

\subsection{Pembuatan bubur bayi instan}

Semua bahan untuk proses pembuatan bubur bayi seperti air, susu formula, minyak kedelai dan bahan lain yang telah dibentuk pure yang terdiri dari puree labu kuning, puree bayam hijau, puree kacang merah, puree ikan gabus dan puree ikan patin, dilakukan pencampuran untuk semua bahan hingga homogen. Untuk mendapatkan bubur innstant, kemudian dimasukkan kedalam alat pengering Freeze dryer. dan bubur MPASI instan yang dihasilkan di analisis secara fisik mengacu pada metode Fardiaz, dkk. (1992) dan uji organoleptik.

\subsection{Pengujian Kelarutan}

Kelarutan MP - ASI instan dianalisa berdasar berat residu bubur bayi yang tidak dapat lolos melewati kertas saring whatman terhadap berat sampel bubur sebanyak 0,5 gram. Sampel bubur dilakukan penimbangan kemudian dilarutkan dalam $50 \mathrm{ml}$ air campuran dilanjutkan pengadukan untuk memperkecil ukuran agar sampel mudah larut kemudian dditeruskan proses penyaringan menggunakan kertas saring whatman yang telah diketahui bobotnya. Sedangkan untuk sampel yang tidak dapat tersaring kemudian di oven pada suhu $105^{\circ} \mathrm{C}$ selama 1 jam, dilanjutkan proses pendinginan dalam desikator selama 15 menit kemudian ditentukan beratnya dengan cara dilakukan penimbangan. Borat sampel yang tidak tersaring didapatkan dari selisih atau hasil pengurangan bobot kertas saring akhir dengan bobot kertas saring awal

Kelarutan bubur bayi didapatkan dari rumus perhitungan cara sebagai berikut :

Kelarutan $=\left[\left[\frac{\text { berat awal sampel-berat akhir sampel }}{\text { berat awal sampel }}\right] \times 100 \%\right]$

\subsection{Pengujian Daya Serap Air}

Daya serap air ditentukan melalui tahap penyiapan erlenmeyer $250 \mathrm{ml}$, corong, dan kertas saring, setelah itu kertas saring ditimbang kemudian dilipat kertas saring tersebut untuk menghindari kebocoran saat dgunakan penyaringan sampel dan letakkan pada corong, serta menempatkan diatas Erlenmeyer. Menyiapkan $13 \mathrm{ml}$ air panas, kemudian menimbang sampel bubur bayi 1-3 gram dan dituangkan perlahan-lahan diatas kertas saring, mencurahkankan air panas tadi secara perlahan kemudian tunggu sampai 10 menit, setelah itu dilakukan penimbangan kertas saring beserta residunya dan yang terakhir menimbang air yang terdapat pada Erlenmeyer, sehingga kadar daya serap air bisa ditentukan dengan cara perhitungan sebagai berikut :

\section{Daya serap air bubur (\%) $=\frac{A-B}{C}$}

Keterangan:

A : Berat air Awal

B : Berat air yang keluar

C : Berat bubur Sampel

\section{Discussion}

\subsection{Sifat Fisik MP - ASI Bubur Bayi Instan}

\subsubsection{Kelarutan}

Pengertian Kelarutan suatu sampel adalah keadaan suatu bahan atau senyawa baik cair, padat, atau gas yang dapat terlarut pasa suatu cairan, padatan atau gas yang membentuk suatu 
bahan yang bersifat homogen. Kelarutan bergantung pada jenis pelarut yang digunakan (Lachman, 1986). Berikut adalah hasil uji kelarutan sampel bubur bayi MP - ASI instan pada Tabel 1.

Table 1. Hasil Uji Kelarutan Bubur Bayi MPASI Instan

\begin{tabular}{llllllll}
\hline & Kontrol & $\begin{array}{l}\text { Patin } \\
\text { T,5\% }\end{array}$ & $\begin{array}{l}\text { Patin } \\
\mathbf{1 0 \%}\end{array}$ & $\begin{array}{l}\text { Patin } \\
\mathbf{1 2 , 5 \%}\end{array}$ & $\begin{array}{l}\text { Gabus } \\
\mathbf{7 , 5 \%}\end{array}$ & $\begin{array}{l}\text { Gabus } \\
\mathbf{1 0 \%}\end{array}$ & $\begin{array}{l}\text { Gabus } \\
\mathbf{1 2 , 5 \%}\end{array}$ \\
\cline { 2 - 7 } Kelarutan & $47,810^{\mathrm{e}}$ & $41,100^{\mathrm{d}}$ & $37,021^{\mathrm{c}}$ & $35,360^{\mathrm{b}}$ & $40,890^{\mathrm{d}}$ & $35,776^{\mathrm{b}}$ & $33,633^{\mathrm{a}}$ \\
\hline
\end{tabular}

Notasi dengan abjad berbeda menunjukkan beda nyata pada $\alpha=0,05$

Kontrol: tidak ditambah daging ikan

Pada Tabel 1. Kadar kelarutan pada bubur bayi MP - ASI instan berkisar 33,633-47,810\%. Kelarutan suatu produk dalam air merupakan salah satu karakterustik sifat fisik produk bentuk bubuk yang berkorelasi dengan proses rehidrasi dalam penyajian. Kelarutan suatu bahan diartikan sebagai kemampuan bahan untuk dapat larut dalam air (Hidayat, 2009). Kelarutan suatu bahan atau pada bubur bayi instan diharapkan tidak mendekati atau dibawah $100 \%$, Hal ini disebabkan karena dengan kelarutan produk dalam hal ini bubur bayi, dapat larut dengan sempurna di dalam air maka tidak diinginkan atau kurang baik untuk bayi karena maksud dari pemberian makanan pendamping MP - ASI merupaka salah satu usaha memperkenalkan bayi dengan makanan semi padat atau makanan yang berbentuk padat (Husna dkk., 2012). Pada Tabel 1. Bahwa penambahan ikan, baik ikan patin dan ikan gabus memberikan pengaruh nyata. Pada sampel kontrol memiliki nilai tertinggi kelarutan.
Sedangkan rerata untuk kadar kelarutan dengan penambahan ikan patin mengakibatkan kadar kelarutan lebih tinggi dibandingkan dengan pada penambahan ikan gabus. Hal ini juga senada dengan yang disampaikan Winarno (2002) bahwa Semakin tinggi kandungan protein suatu bahan dapat menyebabkan kelarutan suatu bahan semakin meningkat atau baik.

\subsubsection{Daya Serap Air}

Mirdhayati (2004), menyampaikan bahwa daya serap air dari suatu bahan sangat dipengaruhi oleh berbagai unsur komponen penyusunnya seperti protein, dimana salah satu sifat protein adalah bersifat menyerap air. Dari hasil penelitian bahwa semakin bertambah konsenrasi ikan baik ikan patin dan ikan gabus, semakin tinggi nilai daya serap air. Berikut disajikan Tabel 2 hasil uji daya serap air sampel bubur bayi MP - ASI instan.

Table 2. Hasil Uji Daya Serap Air Bubur Bayi MPASI Instan

\begin{tabular}{llllllll}
\hline & Kontrol & $\begin{array}{l}\text { Patin } \\
\mathbf{7 , 5 \%}\end{array}$ & $\begin{array}{l}\text { Patin } \\
\mathbf{1 0 \%}\end{array}$ & $\begin{array}{l}\text { Patin } \\
\mathbf{1 2 , 5 \%}\end{array}$ & $\begin{array}{l}\text { Gabus } \\
\mathbf{7 , 5 \%}\end{array}$ & $\begin{array}{l}\text { Gabus } \\
\mathbf{1 0 \%}\end{array}$ & $\begin{array}{l}\text { Gabus } \\
\mathbf{1 2 , 5 \%}\end{array}$ \\
\cline { 2 - 7 } Daya Serap Air & $4,220^{\mathrm{d}}$ & $2,016^{\mathrm{c}}$ & $2,057^{\mathrm{b}}$ & $2,0437^{\mathrm{b}}$ & $0,882^{\mathrm{a}}$ & $1,247^{\mathrm{a}}$ & $1,500^{\mathrm{a}}$ \\
\hline
\end{tabular}

Notasi dengan abjad berbeda menunjukkan beda nyata pada $\alpha=0,05$

Kontrol: tidak ditambah daging ikan

Dari Tabel 2, nilai daya serap air pada hasil penelitian berkisar $0,882-4,220 \mathrm{~g} / \mathrm{gr}$. Penelitian oleh Lumentut (2018), bahwa daya serap air produk bubur bayi MP - ASI instan komersial berkisar 3,60 - 6,20 gr/gr. Tepung labu kuning yang ditambahkan semakin banyak dapat menaikkan daya serap air bubur bayi instan. Hal ini disebabkan tepung labu kuning bersifat higroskopis yang mengakibatkan bubur bayi yang dihasilkan lebih mudah menyerap air. Kadar karbohidrat pada labu kuning yang berupa gula juga bersifat hidrofilik yang dapat memperbesar peningkatan daya serap air. Daya serap air bubur bayi juga dipengaruhi oleh unsur penyusun yang lain yatu lemak. Kadar lemak pada bubur atau bahan pangan yang semakin 
tinggi akan menyebabkan menurunnya kemampuan bahan dalam menyerap air (Farida, 2016). Pada hasil penelitian semakin tinggi konsentrasi ikan, baik ikan patin maupun ikan gabus semakin tinggi daya serap air bubur bayi instan. Dalam Lumentut (2018), protein yang tinggi bersifat hidrofilik sehingga lebih mudah menyerap air. Pendapat ini sesuai dengan Alsuhendra dan Ridawati (2009), menyampaikan bahwa daya serap air juga dipengaruhi oleh kadar karbohidrat, baik pati ataupun serat kasar, serta protein dan komponen penyusunnya terutama yang bersifat hidrofilik. Diketahui bahwa kandungan protein ikan patin sebesar 68,6\% (Atika, 2014) sedangkan ikan gabus 25,5\% (Carvalo, 1998). Sehingga kadar daya serap air pada penelitian ini, sampel produk ikan patin lebih tinggi daripada ikan gabus.

\subsection{Uji Sensoris}

Dalam pengembangan suatu produk, pada akhirnya penerimaan konsumen menjadi hal yang sangat penting sebagai bahan pertimbangan. Metode yang biasa digunakan adalah pengujian sensoris atau uji inderawi yang dipakai oleh suatu perusahaan untuk tujuan pengembangan produk baru, monitoring dan evaluasi kompetisi dengan produk dari perusahaan atau merk lain, pengawasan serta pengendalian mutu stabilitas produk selama penyimpanan, monitoring pendapat atau kesenangan konsumen dari produk tersebut. Tahapan pada penilaian suatu bahan pada makanan pertama setalah bahan makanan diterima akan segera diamati bentuk dan warnanya. Setelah itu aroma. Pada saat mengunyah terjadi pengamatan ke beberapa sifat inderawi rasa, tekstur akan teramati selama makanan tersebbut terkunyah. Akhir mutu bahan makanan dapat dievaluasi secara kesuluruhan atau overall (Kartika, 1988). Berikut adala Tabel 3 hasil uji organoleptik semua parameter produk bubur bayi MP - ASI instan.

Table 3. Hasil Uji Organoleptik Bubur Bayi MP -ASI Instan

\begin{tabular}{llllllll}
\hline & Kontrol & $\begin{array}{l}\text { Patin } \\
\text { W,5\% }\end{array}$ & $\begin{array}{l}\text { Patin } \\
\mathbf{1 0 \%}\end{array}$ & $\begin{array}{l}\text { Patin } \\
\mathbf{1 2 , 5 \%}\end{array}$ & $\begin{array}{l}\text { Gabus } \\
\mathbf{7 , 5 \%}\end{array}$ & $\begin{array}{l}\text { Gabus } \\
\mathbf{1 0 \%}\end{array}$ & $\begin{array}{l}\text { Gabus } \\
\mathbf{1 2 , 5 \%}\end{array}$ \\
\cline { 2 - 7 } Warna & $3,36^{\mathrm{a}}$ & $3,24^{\mathrm{a}}$ & $3,08^{\mathrm{a}}$ & $3,04^{\mathrm{a}}$ & $3,48^{\mathrm{a}}$ & $3,76^{\mathrm{a}}$ & $3,64^{\mathrm{a}}$ \\
Aroma & $2,88^{\mathrm{a}}$ & $3,28^{\mathrm{a}}$ & $3,20^{\mathrm{a}}$ & $3,32^{\mathrm{a}}$ & $2,96^{\mathrm{a}}$ & $3,36^{\mathrm{a}}$ & $3,32^{\mathrm{a}}$ \\
Rasa & $2,24^{\mathrm{a}}$ & $2,64^{\mathrm{a}}$ & $2,60^{\mathrm{a}}$ & $3,16^{\mathrm{b}}$ & $3,00^{\mathrm{b}}$ & $3,48^{\mathrm{c}}$ & $3,28^{\mathrm{c}}$ \\
Tekstur & $3,20^{\mathrm{a}}$ & $3,08^{\mathrm{a}}$ & $3,16^{\mathrm{a}}$ & $3,40^{\mathrm{a}}$ & $3,24^{\mathrm{a}}$ & $3,16^{\mathrm{a}}$ & $3,56^{\mathrm{a}}$ \\
Overall & $2,80^{\mathrm{a}}$ & $2,96^{\mathrm{a}}$ & $3,08^{\mathrm{ab}}$ & $3,32^{\mathrm{a}}$ & $3,20^{\mathrm{a}}$ & $3,80^{\mathrm{b}}$ & $3,64^{\mathrm{c}}$ \\
\hline
\end{tabular}

Notasi dengan abjad berbeda menunjukkan beda nyata pada $\alpha=0,05$

Kontrol: tidak ditambah daging ikan

\subsubsection{Warna}

Tabel 3. Menunjukkan parameter warna bahwa kesemua sampel tidak berbeda nyata. Hal ini dapat dilihat pada letak subset yang sama pada semua sampel. Baik pada penambahan ikan patin dan ikan gabus semua sampel bubur bayi instan menunjukkan nilai netral. Hal ini dapat diperjelas nilai parameter warna berkisar 3,04 3,76. Demikian juga penambahan labu kuning tidak berpengaruh nyata terhadap warna, Hal senada juga disampaikan oleh Anam (2010) yang menyampaikan penambahan labu kuning pada mie yang terbuat dari subsitusi labu kuning tidak berbeda nyata teradap rasa, aroma dan warna dari mie yang dihasilkan. Dalam uji organoleptik, hal pertama dari suatu produk dinilai biasanya dengan menggunakan mata yaitu melihat warna yang ditampilkan oleh produk. Banyak paremeter sifat komoditi produk yang berhubungan dengan warna. Kemudian selepas melihat warna akan muncul ketertarikan akan produk tersebut atau tidak karena warna biasanya berkaitan dengan cita rasa suatu produk (Soekarto,1980). Pada parameter warna bubur bayi instan, rata - rata panelis menyukai warna sampel bubur bayi instan dengan penambahan ikan gabus $10 \%$. Hasil warna pada penelitian ini, 
sampel setelah direhidrasi dengan air hangat menghasilkan warna hijau gelap. Beberapa faktor yang dapat mempengaruhi warna sampel bubur bayi instan bisa disebabkan tingkat komposisi kacang, ikan, suhu pengeringan dan lama pengeringan (Tienchen, 2016). Penelitian oleh Tienchen (2016), bahwa nilai peringkat warna yang rendah dapat menurunkan tingkat penerimaan karena parameter warna merupakan atribut penting bagi konsumen untuk menyukai suatu produk.

\subsection{Aroma}

Pada Tabel 3 dapat dilihat parameter aroma bahwa kesemua sampel tidak berbeda nyata. Hal ini dapat dilihat pada letak subset yang sama pada semua sampel. Hasil penelitian pada parameter aroma, sampel bubur bayi instan dengan ikan patin dan ikan gabus beraroma amis. Pada Tabel 3, nilai parameter aroma berkisar $2,88-3,36$. Sampel yang mendapat nilai terbaik dari parameter aroma adalah sampel bubur bayi MP - ASI instan penambahan ikan gabus $10 \%$. Persentase penambahan ikan patin dan ikan gabus yang tinggi dapat menyebabkan aroma amis yang tajam. Dalam Standar Nasional Indonesia pemakaian perisa dapat digunakan untuk menutup aroma amis. Adapun perisa yang dapat digunakan untuk MP - ASI antara lain vanilin dengan kadar tidak lebih dari $7 \mathrm{gr} / 100 \mathrm{gr}$ bahan (Standar Nasional Indonesia, 2005). Dalam penelitian oleh Ardhianditto (2012), flavor atau aroma langu bisa dihilangkan dengan penambahan pisang ambon sebagai flavor. Maka dari hasil penelitian ini, sampel bubur bayi MP ASI instan yang masih ada bau amis dapat dihilangkan dengan penambahan pisang ambon sebagai flavor pada bubur bayi instan. Pada hasil penelitian ini memiliki nilai aroma yang hampir sama oleh penelitian Adebayo-Oyetoro et al., (2013) yaitu range dari penelitian berkisar 2,3 3,1 dimana bahan yang digunakan adalah sorgum, kacang walnut, dan jahe. Nilai yang rendah pada parameter aroma juga dapat menurunkan tingkat penerimaan sampel bubur bayi instan.

\subsubsection{Rasa}

Pada Tabel 3 parameter rasa antar sampel bubur bayi instan kontrol dengan sampel bubur bayi insatn ikan patin $12,5 \%$ dan semua sampel bubur bayi instan ikan gabus menunjukkan beda nyata. Perbedaan nyata ini, bisa disebabkan oleh konsentrasi dari ikan patin dan ikan gabus. Nilai uji organoleptik rasa hasil penelitian berkisar $2,24-3,48$. Sampel bubur bayi dengan nilai terbaik pada parameter rasa adalah sampel bubur bayi instan dengan ikan gabus $10 \%$. Panelis memberikan tingkat kesukaan pada rasa untuk semua sampel bubur bayi penambahan ikan patin dengan nilai agak tidak suka. Sedangkan untuk sampel bubur bayi penambahan ikan gabus panelis memberikan nilai netral. Panelis juga memberikan catatan untuk rasa yang dihasilkan manis dan gurih. Rasa manis yang timbul pada sampel karena adanya bahan baku susu formula yang digunakan pada sampel. Dari Tabel 3, sampel bubur bayi instan ikan patin $7,5 \%$ dan $10 \%$ tidak berbeda nyata dengan kontrol. Untuk semua sampel dengan ikan gabus berbeda nyata. Panelis memberikan skor nilai untuk sampel bubur bayi instan dengan ikan gabus lebih baik daripada ikan patin.

\subsubsection{Tekstur}

Tabel 3 juga menunjukkan parameter tekstur bahwa kesemua sampel tidak berbeda nyata. Hal ini dapat dilihat pada letak subset yang sama pada semua sampel. Sampel bubur bayi instan dengan nilai terbaik pada sampel bubur bayi instan dengan ikan gabus $12,5 \%$. Dalam SNI (2005), MP-ASI instan juga harus berupa partikel dengan ukuran cukup untuk memacu bayi agar dapat mengunyah. Ambarsari (2009), menyatakan bahwa tingkat kehalusan produk tepung yang dipersyaratkan umumnya minimal 80 mesh, bahkan sebagian besar perusahaan swasta atau eksportir menetapkan standar yang lebih ketat yaitu sebesar 100 mesh guna menghasilkan tepung dengan tingkat kehalusan tinggi. Salah satu syarat kriteria kualitas tepung yang baik yaitu jika minimal $90 \%$ produk tersebut lolos setelah dilewatkan pada ayakan 80 mesh. Sebagai perbandingan regulasi yang berlaku di Indonesia, tingkat kehalusan tepung terigu yang diperkenankan oleh SNI 01-37512006 yaitu minimal $95 \%$ harus lolos ayakan 80 mesh. Hasil ayakan bubur instan yang tingkat kehalusannya kurang dari 80 mesh dapat menyebabkan tekstur berpasir pada bubur bayi 
instan. Penelitian oleh Tienchen (2016), parameter tekstur pada bubur bayi instan sangat penting karena akan menentukan jumlah makanan yang akan dikonsumsi oleh bayi. Dikarenakan bayi berusia $0-6$ bulan hanya dapat menelan produk bubur yang halus dan bukan yang kasar. Bubur bayi yang kental akan membutuhkan peningkatan upaya untuk menelan, oleh karena itu bubur bayi yang kental akan mengurangi asupan gizi makanan pada bayi yang belum bisa mengembangkan kemampuan menelannya (King, 1987).

\subsubsection{Overall}

Mengacu pada Tabel 3 dapat disampaikan jika variasi formula berpengaruh terhadap tingkat kesukaan panelis terhadap parameter secara keseluruhan atau overall. Rata - rata nilai overall dari semua sampel berkisar 2,8-3,8. Bubur bayi instan yang lebih banyak disukai adalah formulasi dengan penambahan ikan gabus $10 \%$ dan ikan patin dengan penambahan ikan patin $12,5 \%$. Semakin tinggi penambahan ikan pada bubur bayi MP-ASI maka meningkatkan nilai sensoris. Semua atribut berpengaruh pada penilaian overall. Ikan patin maupun gabus dapat memberikan rasa gurih karena mengandung kadar lemak yang tinggi. Faktor - faktor yang mempengaruhi dari penerimaan overall adalah warna, rasa, dan tekstur dari bubur bayi instan (Tienchen, 2016).

\section{Conclusion}

Hasil penelitian yang telah dilakukan memberikan informasi bahwa pada karakteristik fisik kelarutan, semua sampel memiliki nilai dibawah $100 \%$ kadar kelarutan. Pada karakteristik fisik daya serap air, semua sampel telah sesuai dengan nilai kadar daya serap air pada produk bubur bayi instan komersial yang berarti bubur bayi yang dihasilkan telah memenuhi pernyaratan yang telah ditentukan. Pada uji sensoris, hampir semua sampel tidak berbeda nyata dengan sampel kontrol. Pada uji overall, sampel bubur bayi MP - ASI instan yang terbaik pada sampel bubur bayi yang dilakukan penambahan ikan patin $12,5 \%$ dan sampel bubur bayi penambahan ikan gabus $12,55 \%$

\section{References}

[1] Adebayo-Oyetoro, A.O., Olatidoye, O.P., Ogundipe, O.O. and Abayomi, H.T. 2013. Nutrient composition, functional and organoleptic properties of complementary food formulated from sorghum, walnut and ginger. J. Agri. Tech. 9(2), 389-401.

[2] Ambarsari I, Sarjana, Choliq A.2009. Rekomendasi dalam Penetapan Standar Mutu Tepung Ubi Jalar. Balai Pengkajian Teknologi Pertanian (BPTP). Ungaran.

[3] Alsuhendra dan Ridawati. 2009. Pengaruh Modifikasi Secara Pregelatinisasi, Asam, dan Enzimatis terhadap Sifat Fungsional Tepung Umbi Gembili (Dioscoreaesculenta). Jakarta. Universitas Negeri Jakarta.

[4] Ardhianditto, Decca., R. Baskara Katri Anandito., Nur Her Riyadi Parnanto., Dian Rachmawati A. 2013. Kajian Karakteristik Bubur Bayi Instan Berbahan Dasar Tepung Millet Kuning (Panicum sp) dan Tepung Beras Merah (Oryza nivara) dengan Flavor Alami Pisang Ambon (Musa X paradisicia L) sebagai Makanan Pendamping ASI (MPASI). J. Tek. Sains. 2 (1), 88 -96.

[5] Atika Nur Syarifah. 2014. Formulasi dan Karaktrisasi Bubur Bayi Instan Berbahan Dasar Labu Kuning (Curcubita moschata), Bayam (Amaranthus sp), dan Kacang Merah (Phaseolus vulgaris L.). Skripsi. Fakultas Pertanian UNS. Surakarta.

[6] Carvallo. 1998. Studi Profil Asam Amino, Albumin dan Mineral Zn pada Ikan Gabus dan Tomang. Skripsi. Universitas Brawijaya. Malang.

[7] Elvizahro, Leyla. 2011. Kontribusi MP-ASI Bubur Bayi Instan dengan Substitusi Tepung Ikan Patin dan Tepung Labu Kuning terhadap Kecukupan Protein dan Vitamin A pada Bayi. Skripsi. Program Studi Ilmu Gizi Fakultas Kedokteran. Undip Semarang.

[8] Fardiaz S. 1989. Penuntun Praktek Laboratorium Mikrobiologi Pangan. Jurusan Ilmu Dan Teknologi Pangan. IPB.Bogor

[9] Hidayat, Beni., Kalsum Nurbani dan Surfiana. 2009. Karakterisasi Tepung Ubi kayu modifikasi yang diproses menggunakan Metode pragelatinisasi parsial ( Characteristzation pf modified Cassava flour processed Through Partial Pregelatinisation Method). J. Tek. Ind. Pert. 14,(2), $148-159$.

[10] Husna, Emma A., Dian Rachmawati Affandi..Kawiji., R. Baskara Katri Anindito. 2012. Karakterisasi Bubur Bayi Instan Berbahan Dasar Tepung Millet (Panicum sp) dan tepung Kacang Hijau (Phaseolus Radiatus) dengan flavor alami pisang ambon ( Musa Paradisiaca var. Sapientum L).J. Tek. Pang. 1 (1), 68 - 74

[11] Irianto Eko Hari dan Giyatmi. 2020. Mengoptimalkan Ikan sebagai Fortifikasi Protein, Ketahanan dan 
keamanan Pangan Indonesia Searang dan ke Depan, PATPI, Jakarta.

[12] King, J., Ashworth, A. 1987. Changes in Infant Feeding Practices in Nigeria, an Historial Review Ocasional Paper No 9. London School of Hygiene and Tropical Medicine. London UK.

[13] Lachman L., H. Lieberman dan J.N. Kanig. 1986. The Theory and Practice of Industrial Pharmacy Edisi ke3. Lea \& Febriger. USA

[14] Lumentut, Gismawaty. 2018. Formulasi Bubur Bayi Instam dari Tepung Pregelatinisasi Umbi Uwi Ungu (Dioscorea alata L.) Dengan Tepung Kedelai (Glycine max L.Merr) sebagai Alternatif Makanan Pendamping Air Susu Ibu. Skripsi. Ilmu dan Teknologi Pangan Universitas Hasanudin Makassar

[15] Marliyati, S.A., Dongoran, N., Kustiyah, L. 2007. Pembuatan Susu Kedelai Berkalsium Tinggi dengan Penambahan Tepung Tulang Ikan Kakap Merah (Lutjamus Sanguineus). Media Gizi dan Keluarga: LIPI.

[16] Mirdhayati I. 2004. Formulasi dan karakteristisasi sifat-sifat fungsional buburgarut (Maranta arundinaceae Linn) instan sebagai makanan pendampingair susu ibu (MP-ASI). Tesis. Sekolah Pascasarjana, Insititut Pertanian Bogor.
[17] Muchtadi, T.R, 1999. Ilmu Pengetahuan Bahan Pangan. Departemen Pendidikan dan Kebudayaan, Dirjen Pendidikan Tinggi. Bogor; Pusat Antar Universitas Pangan dan Gizi, Institut Pertanian Bogor, Bogor.

[18] Nurilmala, M., Nurjanah dan Utama, R.H. 2009. Kemunduran mutu lele dumbo (Clarias gariepinus)pada penyimpanan suhu chilling dengan perlakuan caramati. J. Peng. Peri. 12(1), 17-22.

[19] Sari, Dewi Kartika., Sri Anna Marliyati., Lilik Kustiyah., Ali Khomsan.,dan Tommy Marcelino Gantohe. 2014. Uji Organoleptik Formulasi Biskuit Funsional Berbasis Tepung Ikan Gabus (Ophiocephalus striatus). J. Agr. 34 (2), 120 - 125.

[20] Soekarto, 1984. Soewarno T. Penilaian Organoleptik, untuk Industri Pangan dan Hasil Pertanian. Bogor: PUSBANGTEPA / Food Technology Development Center, Institut Pertanian Bogor.

[21] Standar Nasional Indonesia tentang bubur bayi MPASI instan. 2005.

[22] Trahms CM, McKean KN.(2008)Nutrition During Infancy. In: Mahan LK, Escott-Stump S. Krause's Food and Nutrition Theraphy 12th edn. Elsevier. Canada

[23] Winarno, F.G. 2002. Kimia Pangan dan Gizi. Gramedia Pustaka Utama. Jakarta. 